\title{
Did near-infrared spectroscopy leave us in the dark?
}

\author{
Elena Ashikhmina, MD, PhD
}

From the Department of Anesthesiology and Perioperative Medicine, Mayo Clinic, Rochester, Minn.

Disclosures: Author has nothing to disclose with regard to commercial support.

Received for publication Nov 10, 2016; accepted for publication Nov 10, 2016; available ahead of print Dec 10, 2016.

Address for reprints: Elena Ashikhmina, MD, PhD, 200 First St SW, Rochester, MN 55905 (E-mail: Ashikhmina. Elena@mayo.edu).

J Thorac Cardiovasc Surg 2017;153:620-1

0022-5223/\$36.00

Copyright (c) 2016 by The American Association for Thoracic Surgery

http://dx.doi.org/10.1016/j.jtcvs.2016.11.020

In this issue of the Journal, Stowell and colleagues ${ }^{1}$ compare the results of tissue oxygenation measurements in cardiac surgical patients after transfusion of packed red blood cells (PRBCs) with shorter or longer storage duration. The study attempted to fill in two knowledge gaps. (1) Does it matter whether older or newer units of PRBCs are being transfused? (2) Ultimately, do we help or harm our patients by transfusing?

A large body of recent literature demonstrates that despite a logical assumption that fresh PRBCs are better; the clinical outcomes are surprisingly similar between those who received old or new PRBCs. ${ }^{2}$ To find a physiologic explanation for these results, Stowell and colleagues ${ }^{1}$ evaluated tissue oxygenation by near-infrared spectroscopy of the thenar eminence and sublingual microcirculation. Both minimally invasive methods are relatively easy, and in addition some of the coauthors of the article have used an identical protocol on healthy volunteers in the recent past. ${ }^{3}$ As we learn from the article, transfusion of either fresh or old PRBCs did not change the tissue oxygenation much, and thus the transfusion in general might have been pointless.

But can one be sure that not too many assumptions have been made before drawing these conclusions?

The first assumption is that somatic near-infrared spectroscopy provides an adequate surrogate for the tissue perfusion on the basis of which one could accurately judge red blood cells' oxygen delivery and capacity to remove carbon dioxide. ${ }^{4}$ Perhaps, but would the changes persist hours after the transfusion, when the measurements were actually performed? The lack of cardiac output data, mixed venous saturation values, and lactate levels before and after measurements also makes the interpretation of the results difficult. In addition, the study group was small.

The second assumption is that because the tissue oxygenation did not change, transfusion may have been futile. There was no group in the study randomly allocated to receive no transfusion, however, so no conclusion can be made as to whether the transfusion was useful.

One more assumption is that older and newer PRBCs are significantly different. Some experts argue that erythrocyte

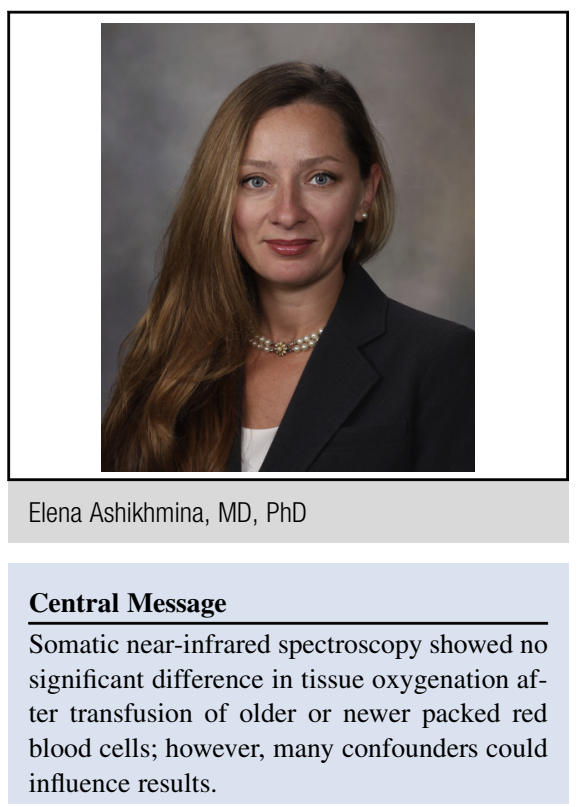

See Article page 610

deterioration unfortunately occurs within just a few hours after cooling to $4^{\circ} \mathrm{C}$. It is to be hoped that the application of the new "-omic" technologies might provide some insight into what happens with intracellular metabolites and membranes of red cells after cooling. Cryopreservation might be a better way to protect erythrocytes function in the future. ${ }^{5}$

Unfortunately, because of the current lack of clinically applicable technology, we are forced to acquire the knowledge from surrogate measurements. For both medieval doctors who believed in therapeutic bleeding and 20th century doctors who believed in transfusions, the knowledge was largely based on assumptions, and the truth remained in the dark.

Stowell and colleagues' point, however, is well taken; there are no axioms in medicine, and widely accepted dogmas can and should be questioned. Taking it "with a grain of salt," we now know that according to near-infrared spectroscopy, tissue oxygenation did not change after transfusion of either older or fresher units of PRBCs. In that case, should we transfuse at all? More research is clearly needed in the near future.

\section{References}

1. Stowell CP, Whitman G, Granger S, Gomez H, Assmann SF, Massey MJ, et al. The impact of red blood cell storage duration on tissue oxygenation in Cardiac Surgery. J Thorac Cardiovasc Surg. 2017;153:610-9.e2. 
2. Remy KE, Spinella PC. Red blood cell storage age-what we know from clinical trials. Expert Rev Hematol. 2016;9:1011-3.

3. Roberson RS, Lockhart E, Shapiro NI, Bandarenko N, McMahon TJ, Massey MJ, et al. Impact of transfusion of autologous 7- versus 42-day-old AS-3 red blood cells on tissue oxygenation and the microcirculation in healthy volunteers. Transfusion. 2012;52:2459-64.
4. Morel J, Bouchet JB, Vola M, Béraud AM, Clerc M, Awad S, et al Tissue near infra red spectroscopy change is not correlated with patients' outcome in elective cardiac surgery. Acta Anaesthesiol Scand. 2014;58: 835-42.

5. Glynn S, Klein H, Ness P. The red blood cell storage lesion: the end of the beginning. Transfusion. 2016;56:1462-8. 